\title{
Effects of Stealth Liposomal Daunorubicin Plus Tamoxifen on the Breast Cancer and Cancer Stem Cells
}

\author{
Jia Guo, Jie Zhou, Xue Ying, Ying Men, Ruo-Jing Li, Yan Zhang, Ju Du, Wei Tian, Hong-Juan Yao, Xiao-Xing Wang, \\ Rui-Jun Ju, Wan-Liang Lu \\ State Key Laboratory of Natural and Biomimetic Drugs, and School of Pharmaceutical Sciences, Peking University, \\ Beijing, China.
}

Received, February 17, 2010; Revised, February 30, 2010; Accepted, May 4, 2010; Published, May 9, 2010.

\begin{abstract}
Purpose: The cancer stem cells play an important role in the invasion, metastasis and relapse of cancers as they are resistant to regular chemotherapy. In the present study, stealth liposomal daunorubicin plus tamoxifen was developed for eradicating breast cancer cells together with cancer stem cells. Methods: Inhibitory effects were performed on the bulk human breast cancer cells (MCF-7), the sorted MCF-7 cancer stem-like cells (side population, SP), and the sorted MCF-7 cancer cells (NSP), respectively. Antitumor activity and TUNEL analysis were evaluated on the MCF-7 xenografts in nude mice. Results: The encapsulation efficiencies of daunorubicin and tamoxifen were $95 \%$ and $90 \%$, respectively. The mean particle size of the stealth liposomes was about $100 \mathrm{~nm}$. Breast cancer stem cells were identified by the specific markers CD44+/CD24-, and isolated from bulk MCF-7 cells. When applying stealth liposomal daunorubicin plus tamoxifen, the inhibitory effects on both the breast cancer cells and the cancer stem cells were significantly increased in vitro, respectively. In the MCF-7 xenografts in mice, stealth liposomal daunorubicin plus tamoxifen showed the most favorable antitumor activity due to the passive targeting the tumor tissue and the synergistic effects in eliminating breast cancer cells and cancer stem cells. Conclusions: Stealth liposomal daunorubicin plus tamoxifen could have the potentials in eliminating both breast cancer cells and cancer stem cells.
\end{abstract}

\section{INTRODUCTION}

Breast cancer usually starts in the breast in the inner lining of the milk ducts or lobules. It has been classified into different types (low, high and intermediate grade), and is the fifth most common cause of cancer death ( $7 \%$ of cancer deaths) (1). In virtually all cases, breast cancer death results from the process of excess proliferation, invasion and metastasis (2).

Cancer stem cells have recently been identified in various malignant tumors, ranging from leukemia to solid tumors including breast cancer. Evidence indicates that the cancer stem cells play an important role in the pathogenesis, invasion and metastasis of malignancies (3, 4). Cancer stem cells represent only a small fraction of a tumor, as they possess the capability of self-renew and differentiation which lead to high tumorigenesis, and most cancer cells lack this regenerative capability. Standard chemotherapeutic agents can hardly kill them, as the special properties of cancer stem cells render their resistance to drug treatment. For instance, cancer stem cells have more efficient DNA damage repair mechanisms and can activate DNA damage check points easier. In addition, cancer stem cells overexpress the ATP-binding cassette $(\mathrm{ABC})$ transporters, which are able to protect the cancer stem cells from drug damage via efflux pumping mechanism (5-7). When patients are treated with cytotoxic agents like daunorubicin, the tumor masses may be shrunken obviously but a small population of cancer stem cells still remained alive due to their resistance. Consequently, the residual cancer stem cells lead to relapse and metastasis of cancer (8).

Corresponding Author: Wan-Liang Lu, Ph.D, Professor, Deputy Chair, Department of Pharmaceutics School of Pharmaceutical Sciences, Peking University, Xueyuan Road 38, Beijing, China, E-mail: luwl@bjmu.edu.cn 
Several potential strategies are suggested for the cancer therapy by targeting the cancer stem cells. The first strategy is to target molecular signaling pathways (Wnt etc.) by regulating the proliferation, differentiation and self-renewal of cancer stem cells. Components of these pathways provide new targets for inducing harmful damage to cancer stem cells. The selective anti-Wnt antibodies, Wnt protein inhibitors or repressors disrupting nuclear LEF/TCF/ $\beta$-catenin complexes could counteract the nuclear accumulation of $\beta$-catenin, thus inhibiting proliferation and maintenance of cancer stem cells (9). The second strategy is an immunotherapeutic approach. Several clinical protocols involve the activation of a patient's immune cells against the cancer cells, or the transplant of bone-marrow stem cells from a donor to kill the tumor cells in the recipient. Purified tumor stem cells isolated were lethally irradiated and used to 'immunize' the patient or to activate the donor's immune cells against the tumor stem cells (5). The third potential strategy is to target $A B C$ transporters (especially ABCG2) to overcome the resistance of the cancer stem cells $(5,10)$. Co-treatment of ABCG2 inhibitors either before or during chemotherapy might help eliminate tumour stem cells. Two compounds (GF120918 and tariquidar) that inhibit both $\mathrm{ABCG} 2$ and $\mathrm{ABCB} 1$ are already approved for clinical studies. Another example is imatinib which decreases the SP subset of head-and-neck squamous carcinoma cells, and allows greater doxorubicin retention, which may due to the inhibition of Akt which eventually regulates $A B C G 2$ function (11). In addition, some other strategies are proposed by modulating the cancer stem cells using certain cytokines, such as G-CSF, GM-CSF, IL-3, IL-6 and IFN-a (10) or by inducing differentiation of the cancer stem cells with a inducer like all-trans retinoic acid (12).

It has been demonstrated that the breast cancer stem cells express specific surface markers CD44+/CD24- $(13,14)$. They were able to be sorted by the side population (SP) (15) using dual-wavelength flow cytometry. Cancer stem cells express high levels of $\mathrm{ABC}$ drug transporters which make cancer stem cells efflux cell-permeable DNA-binding dye Hoechst 33342, while cancer cells accumulate this dye $(7,10)$. This technique has also been used for sorting the SP cells in other tumors, including glioma tumor (16), hepatocarcinoma (17), thyroid tumor (18), colorectal cancer (19), and ovarian carcinoma (20).
Stealth liposomes coated with the synthetic polymer polyethyleneglycol (PEG) had longer blood exposure with an increased half-life due to the highly hydrophilic polymers that inhibit phagocytotic protein recognition by opsonization. Accordingly, the PEG-coated drug-loaded stealth liposomes accumulate more in the solid tumors through passive diffusion, exhibiting an enhanced permeability and retention effect (EPR effect) because of the suitable pore size of vasculature in solid tumor ranging from 100 to $780 \mathrm{~nm}$ (21).

Daunorubicin (DNR) is a cell cycle non-specific anthracycline antibiotic and has been used in treating a wide range of cancers (22-24). Its antineoplastic mechanisms are associated with DNA topoisomerase II inhibition, DNA intercalation, RNA synthesis inhibition, cell membranes interaction, free radical production and induction of apoptosis (25-27). However, the clinical use of daunorubicin is hampered by two major problems, namely, cardiotoxicity (28) and drug resistance. Previous studies showed that daunorubicin is a substrate for P-glycoprotein (MDR1; ABCB1) (29) and for breast cancer resistance protein (BCRP; ABCG2) (5), resulting in the resistance of daunorubicin. Tamoxifen is a selective estrogen receptor modulator that is widely used as the adjuvant therapy for breast cancer. It produces therapeutic efficacy in breast cancer by binding to the estrogen receptor, by inhibiting protein kinase $\mathrm{C}$ activity (30) or by up-regulating p53 expression (31). In addition, tamoxifen exhibits P-glycoprotein-reversing (32) and BCRP-reversing activities (33), suggesting that it may potentially be capable of killing the cancer stem cells. Therefore, we hypothesize that the stealth liposomal system by incorporating daunorubicin plus tamoxifen into the same liposomal vesicle would be able to eliminate cancer cells and to eradicate cancer stem cells. Accordingly, the objectives of the present study were to construct the stealth liposomal daunorubicin plus tamoxifen, and evaluate its potentials for eliminating both breast cancer cells and cancer stem cells.

\section{MATERIALS AND METHODS}

\section{Materials}

Daunorubicin hydrochloride was purchased from Nanjing Tianzun Zezhong Chemicals, Co. Ltd, (Nanjing, China). Tamoxifen citrate was kindly 
provided by Peking University Pharmaceuticals Co., Ltd. (Beijing, China). Egg phosphatidyl - choline (EPC) and polyethylene glycol-distearoyl Phosphatidylethanolamine ( $\mathrm{PEG}_{2000}$-DSPE) were purchased from NOF Corporation (Tokyo, Japan). Cholesterol was purchased from Beijing Shuangxuan Microbial Media Products Plant (Beijing, China). Sulforhodamine B (SRB) was purchased from Biodee Biotechnology Co. Ltd. (Beijing, China). Hoechst 33342 was purchased from Sigma-Aldrich Corporation (Bejing local agent, China). Verapamil hydrochloride was purchased from National Institute for the Control of Pharmaceutical and Biological Products (Bejing, China). All other solvents and reagents used were of chemical grade.

\section{Preparations and characterization of the stealth liposomes}

Stealth liposomal daunorubicin plus tamoxifen was prepared using an ammonium sulfate gradient loading method as reported previously $(14,34,35)$. For experimental comparisons or convenience in treating with various concentrations of drugs, other two types of liposomes were prepared including stealth liposomal daunorubicin and stealth liposomal tamoxifen.

To prepare stealth liposomal daunorubicin, egg phosphatidyl - choline (EPC), cholesterol and polyethylene glycol - distearoyl - phosphatidy lethanolamine (PEG2000-DSPE) (55/40/5, $\mu \mathrm{mol} / \mu \mathrm{mol})$ were dissolved in chloroform in a pear-shaped flask. The chloroform was removed by evaporation with a rotary vacuum evaporator, and the lipid film was hydrated with $250 \mathrm{mM}$ ammonium sulfate followed by sonication for 0.5 min with a water bath sonicator. Afterwards, the blank liposomes were obtained, and successively extruded through polycarbonate membranes (Millipore, Bedford, MA, USA) with pore size of $400 \mathrm{~nm}$ and $200 \mathrm{~nm}$ for 2 times, respectively. After dialysis (12000-14000 molecular mass cutoff) against the Hepes buffered saline (HBS, $25 \mathrm{nM}$ Hepes/150 nM NaCl) for 4 times, blank liposomes were mixed with an appropriate volume of daunorubicin hydrochloride HBS buffer, incubated at $60{ }^{\circ} \mathrm{C}$ water bath, and intermittently shaken for $25 \mathrm{~min}$.

To prepare stealth liposomal tamoxifen, EPC, cholesterol, PEG2000-DSPE $(55 / 40 / 5, \mu \mathrm{mol} / \mu \mathrm{mol})$ and tamoxifen were dissolved in chloroform in a pear-shaped flask. The following procedures were the same with those of blank liposomes.

Stealth liposomal daunorubicin plus tamoxifen was prepared with a combination procedure, namely, after preparation of stealth liposomal tamoxifen, daunorubicin was loaded with the same method as that of stealth liposomal daunorubicin.

The drug-loaded liposomes were separated from un-encapsulated daunorubicin or un-encapsulated tamoxifen by passing the liposomes over a Sephadex G-50 column equilibrated with HBS buffer, and the encapsulation efficiencies for both agents were estimated. The mean particle sizes, polydispersity index (PDI) and zeta potential values were measured using Nano Series Zen 4003 Zeta Sizer (Malvern instruments, Ltd, UK).

\section{Cell culture}

The human breast cancer MCF-7 cells (obtained from Institute of Materia Medica, Chinese Academy of Medical Sciences and Peking Union Medical College, Beijing, China) were routinely grown in Dulbecco's Modified Eagle's Medium (DMEM, high glucose) supplemented by $10 \%$ heat-inactivated fetal bovine serum (FBS), containing antibiotics (penicillin 100U/ml, streptomycin $100 \mu \mathrm{g} / \mathrm{ml}$ ) and L-glutamine (Tianrun Shanda Biotech Co., Ltd, Beijing, China). Cells were grown at $37^{\circ} \mathrm{C}$ and in the presence of $5 \% \mathrm{CO}_{2}$. In the logarithmic phase of growth, cells were used for drug sensitivity assays.

\section{Bulk breast cancer cells drug treatment}

MCF-7 cells in the logarithmic phase of growth were harvested, washed, and seeded into 96 well plates at a concentration of 5000 cells per well. After $24 \mathrm{~h}$ for attachment, a series of drug formulations were added into the wells, including free daunorubicin $(0-2.5 \mu \mathrm{M})$, free tamoxifen $(0-$ $50 \mu \mathrm{M})$, various concentrations of free daunorubicin $(0-2.5 \mu \mathrm{M})$ co-treated with free tamoxifen $(0-10 \mu \mathrm{M})$, stealth liposomal daunorubicin $(0-2.5 \mu \mathrm{M})$, stealth liposomal tamoxifen $(0-50 \mu \mathrm{M})$, various concentrations of stealth liposomal daunorubicin $(0-2.5 \mu \mathrm{M})$ co-treated with stealth liposomal tamoxifen $(0-10$ $\mu \mathrm{M})$.

The cytotoxicity was measured at $48 \mathrm{~h}$ later by sulforhodamine B (SRB) staining assay (36), and 
the absorbance was read on a microplate reader (BIO-RAD Model 680, Bio-Rad Laboratories, Inc. Shanghai, China) at the wavelength of $540 \mathrm{~nm}$. The SRB assay was based on the uptake of the negatively charged pink aminoxanthine dye, sulphorhodamine B (SRB) by basic amino acids in the cells. The greater the number of cells, the greater amount of dye is taken up and, after fixing, when the cells are lysed, the released dye will give a more intense colour and greater absorbance (37). The viability percentages were calculated using the following formula: viability $\%=\left(\mathrm{A}_{540 \mathrm{~nm}}\right.$ for the treated cells $/ \mathrm{A}_{540 \mathrm{~nm}}$ for the control cells) $\times 100 \%$, where $A_{540 \mathrm{~nm}}$ is the absorbance value. Each assay was repeated minimum of three times.

\section{Identification and isolation of SP cells}

To isolate the breast cancer stem-like cells (SP cells), human breast cancer MCF-7 cells were harvested by trypsinization at about $80 \%$ confluence, washed and suspended at $1 \times 10^{6}$ cells per $\mathrm{ml}$ in medium (DMEM containing $2 \% \mathrm{FBS}$ ), and pre-warmed at $37^{\circ} \mathrm{C}$ for $10 \mathrm{~min}$. The cells were then labeled in the same medium for $90 \mathrm{~min}$ at $37^{\circ} \mathrm{C}$ with $4 \mu \mathrm{g} / \mathrm{ml}$ of fluorescent dye Hoechst 33342 plus $200 \mu \mathrm{M}$ verapamil hydrochloride (or without adding verapamil hydrochloride). Hoechst exclusion was inhibited by verapamil, which serves as an inhibitor of $\mathrm{ABC}$ transporters (38). Then cells were re-suspended at $1 \times 10^{6}$ cells per $\mathrm{ml}$ in the medium and filtered through a $40-\mu \mathrm{m}$ cell strainer to obtain the single cell suspensions. Finally, cells were stained with $1 \mu \mathrm{g} / \mathrm{ml}$ of propidium iodide to label dead cells. Cell analysis and sorting were performed on a FACSDiva (Becton Dickinson, San Jose, CA, USA) by using a dual-wavelength analysis (blue, 420-470 nm; red, 660-680 nm). Propidium iodide-positive dead cells were excluded from the analysis, and $1 \times 10^{4}$ cells were analyzed (9). Each experiment was repeated at least three times.

To characterize the cell-surface phenotype of SP cells, the SP subpopulation of MCF-7 cells were sorted, and immuno-stained with anti-CD44-FITC, anti-CD24-PE and their appropriate isotype controls (Becton Dickinson, San Jose, CA, USA) on ice for $20 \mathrm{~min}$ in staining buffer (pH 7.4 PBS + $2 \% \mathrm{FBS}$ ), after which the sample was washed twice with cold PBS (pH 7.4) and re-suspended in $500 \mu \mathrm{l}$ (per $10^{5}$ cells) of cold PBS. Flow cytometry was performed on a FACScan flow cytometer (Becton
Dickinson, San Jose, CA, USA). Side scatter and forward scatter profiles were used to eliminate cell doublets (13).

\section{Breast cancer stem-like cells drug treatment}

To evaluate cytotoxicity to the breast cancer stem-like cells after applying the stealth liposomal daunorubicin co-treated with stealth liposomal tamoxifen, the SP cells and NSP cells of MCF-7 cells were cultured as the following procedure. Briefly, the sorted SP and NSP cells were seeded into the 96 -well plates at 2,000 cells in $100 \mu$ of medium per well. After incubation for $24 \mathrm{~h}$, various drug formulations were added, including free daunorubicin $(0.5 \mu \mathrm{M})$, free tamoxifen $(1.5 \mu \mathrm{M})$, free daunorubicin $(0.5 \mu \mathrm{M})$ co-treated with free tamoxifen $(1.5 \mu \mathrm{M})$, stealth liposomal daunorubicin $(0.5 \mu \mathrm{M})$, stealth liposomal tamoxifen $(1.5 \mu \mathrm{M})$, and stealth liposomal daunorubicin $(0.5 \mu \mathrm{M})$ co-treated with stealth liposomal tamoxifen (1.5 $\mu \mathrm{M})$, respectively. After further incubation for $48 \mathrm{~h}$, cell viability was estimated by SRB assay.

\section{Tumor-bearing mice drug treatment}

Female BALB/c nude mice ( 6 - 8 weeks of age, initially weighing $19-25 \mathrm{~g}$ ) were obtained from Peking University Health Science Center (Beijing, China). All animal experiments were performed in accordance with the principles of care and use of laboratory animals, and were approved by the Institutional Animal Care and Use Committee of Peking University. Briefly, adherent MCF-7 cells were removed by trypsinization, and the resultant cell suspensions were centrifuged for 5 minutes at $1,000 \mathrm{~g}$ and then re-suspended in serum-free DMEM culture medium. Cell suspensions with approximately $1.5 \times 10^{7}$ MCF-7 cells were subcutaneously injected (s.c.) into right armpits of mice (39). When tumor volumes reached to about $100-150 \mathrm{~mm}^{3}$, nude mice were sacrificed to dissect the tumors. The tumors were cut into approximate $1 \mathrm{~mm}^{3}$ pieces aseptically, and the pieces were transplanted into the right armpits of the nude mice, respectively. Once tumor volumes reach to approximately $200 \mathrm{~mm}^{3}$, mice were randomly divided into nine groups (4-6 each group). At day 18, 20 and 22 after inoculation, various drug formulations were injected into mice via tail vein, respectively. The drug formulations included physiological saline, free daunorubicin $(5 \mathrm{mg} / \mathrm{kg})$, 
free tamoxifen $(2.5 \mathrm{mg} / \mathrm{kg})$, free daunorubicin (5 $\mathrm{mg} / \mathrm{kg})$ co-treated with free tamoxifen $(2.5 \mathrm{mg} / \mathrm{kg})$, stealth liposomal daunorubicin $(5 \mathrm{mg} / \mathrm{kg})$, stealth liposomal tamoxifen $(2.5 \mathrm{mg} / \mathrm{kg})$, stealth liposomal daunorubicin $(5 \mathrm{mg} / \mathrm{kg})$ plus tamoxifen $(5 \mathrm{mg} / \mathrm{kg})$, stealth liposomal daunorubicin $(5 \mathrm{mg} / \mathrm{kg})$ plus tamoxifen $(2.5 \mathrm{mg} / \mathrm{kg})$, and stealth liposomal daunorubicin $(5 \mathrm{mg} / \mathrm{kg})$ plus tamoxifen $(1.25$ $\mathrm{mg} / \mathrm{kg}$ ). After administrations, the tumor volumes of the mice were further monitored daily with a caliper, and evaluated with the formula: $\mathrm{V}=$ length $\times$ width $\times 0.52\left(\mathrm{~mm}^{3}\right)$. The change ratio of tumor volume $(\%)$ at the $i^{\text {th }}$ day was calculated with the formula: $\mathrm{R}=\left(\mathrm{V}_{\mathrm{i}}-\mathrm{V}_{18}\right) / \mathrm{V}_{18} \times 100 \%$, where $\mathrm{R}$ is the change ratio of tumor volume, $V_{i}$ represents the tumor volume at the $\mathrm{i}^{\text {th }}$ day, and $\mathrm{V}_{18}$ indicated the tumor volume at day 18 .

\section{TUNEL analysis}

The tumor-bearing mice were sacrificed at day 29 since the inoculation. Then the tumors were isolated and fixed with terminal deoxynucleotidyl transferase-mediated dUTP-biotin nick end labeling (TUNEL). The DNA fragmentation in tumor masses was analyzed by following the instructions of the manufacturer of an ApopTag plus peroxidase in situ apoptosis detection kit (Intergen Co Ltd., Burlington, MA, USA). Under the light microscope, apoptotic cells showed brownish staining in the nuclei. The digital images of non-necrotic zone were randomly selected in the tissue sections.

\section{STATISTICS}

Data are presented as the mean \pm standard deviation (SD). One-way analysis of variance (AVONA) was used to determine the significance among groups, after which post hoc tests with the Bonferroni correction were used for comparisons between individual groups. A value of $p<0.05$ was considered to be significant.

\section{RESULTS}

\section{Characterization of the stealth liposomes}

Results showed that the encapsulation efficiency of daunorubicin was $\geq 95 \%$ and encapsulation efficiency of tamoxifen was $\geq 90 \%$ in all three kinds of stealth liposomes, respectively. Table 1 shows the mean particle size, polydispersity index
(PDI) and zeta-potential values. The mean particle sizes of all liposomes were approximately $100 \mathrm{~nm}$. The particle size distributions (PDIs) were $0.16 \pm$ 0.01 for stealth liposomal daunorubicin plus tamoxifen, $0.17 \pm 0.01$ for stealth liposomal daunorubicin, and $0.16 \pm 0.0$ for stealth liposomal tamoxifen, respectively. In addition, all liposomes zeta potential values were closed to a neutral state $(-6.5 \pm 0.7 \mathrm{mV}$ for stealth liposomal daunorubicin plus tamoxifen, $-7.2 \pm 1.6 \mathrm{mV}$ for stealth liposomal daunorubicin and $-5.5 \pm 3.7 \mathrm{mV}$ for stealth liposomal tamoxifen).

\section{Effect on bulk breast cancer cells in vitro}

Figure 1 represents the effect on MCF-7 breast cancer cells after applying various formulations. Results showed that free daunorubicin alone significantly inhibited the proliferation of MCF-7 cells, exhibiting a dose dependent manner at low concentrations ranging from 0.25 to $2.5 \mu \mathrm{M}$ (Figure 1.A). Free tamoxifen did not exhibit obvious inhibitory activity to MCF-7 cells at lower concentrations of $2.5-5 \mu \mathrm{M}$. When its concentration increased $(\geq 10 \mu \mathrm{M})$, the inhibitory effect was increased significantly (Figure 1.B). The in vitro inhibitory effects of drug-loaded liposomes were attenuated as compared with those of free drugs, respectively.

When the concentration of free daunorubicin was in the range of $0.25-2.5 \mu \mathrm{M}$, the inhibitory rate was from $12.6 \%$ to $80.8 \%$. The inhibitory effect of free daunorubicin at a fixed concentration $(0.25-2.5 \mu \mathrm{M})$ was increased after co-treating with free tamoxifen $(2.5,5$ and $10 \mu \mathrm{M})$, respectively (Figure 1.C), showing a tamoxifen-dose dependent manner. For instance, when co-applying free daunorubicin $(0.25 \mu \mathrm{M})$ with free tamoxifen $(10 \mu \mathrm{M})$, the inhibitory rate was increased from $12.6 \%$ to $66.2 \%$ as comparing with that applying daunorubicin $(0.25 \mu \mathrm{M})$ alone. The same effect was observed by co-treating stealth liposomal daunorubicin with stealth liposomal tamoxifen (Figure 1. D).

\section{Identification and isolation of the SP cells}

The percentage of SP population was decreased markedly to zero by treatment with verapamil in advance (Figure 2. A), which was consistent with the reports that verapamil could prohibit Hoechst 33342 efflux (16). 
Table 1. The average particle size, polydispersity index (PDI) and zeta potential values of stealth liposomal daunorubicin plus tamoxifen, stealth liposomal daunorubicin and stealth liposomal tamoxifen.

\begin{tabular}{llll}
\hline & Mean size $(\mathrm{nm})$ & Polydispersity index & Zeta potential $(\mathrm{mV})$ \\
\hline Stealth liposomal daunorubicin plus tamoxifen & $99.6 \pm 0.3$ & $0.16 \pm 0.01$ & $-6.5 \pm 0.7$ \\
Stealth liposomal daunorubicin & $96.4 \pm 0.3$ & $0.17 \pm 0.01$ & $-7.2 \pm 1.6$ \\
Stealth liposomal tamoxifen & $93.8 \pm 0.3$ & $0.16 \pm 0.00$ & $-5.5 \pm 3.7$ \\
\hline
\end{tabular}
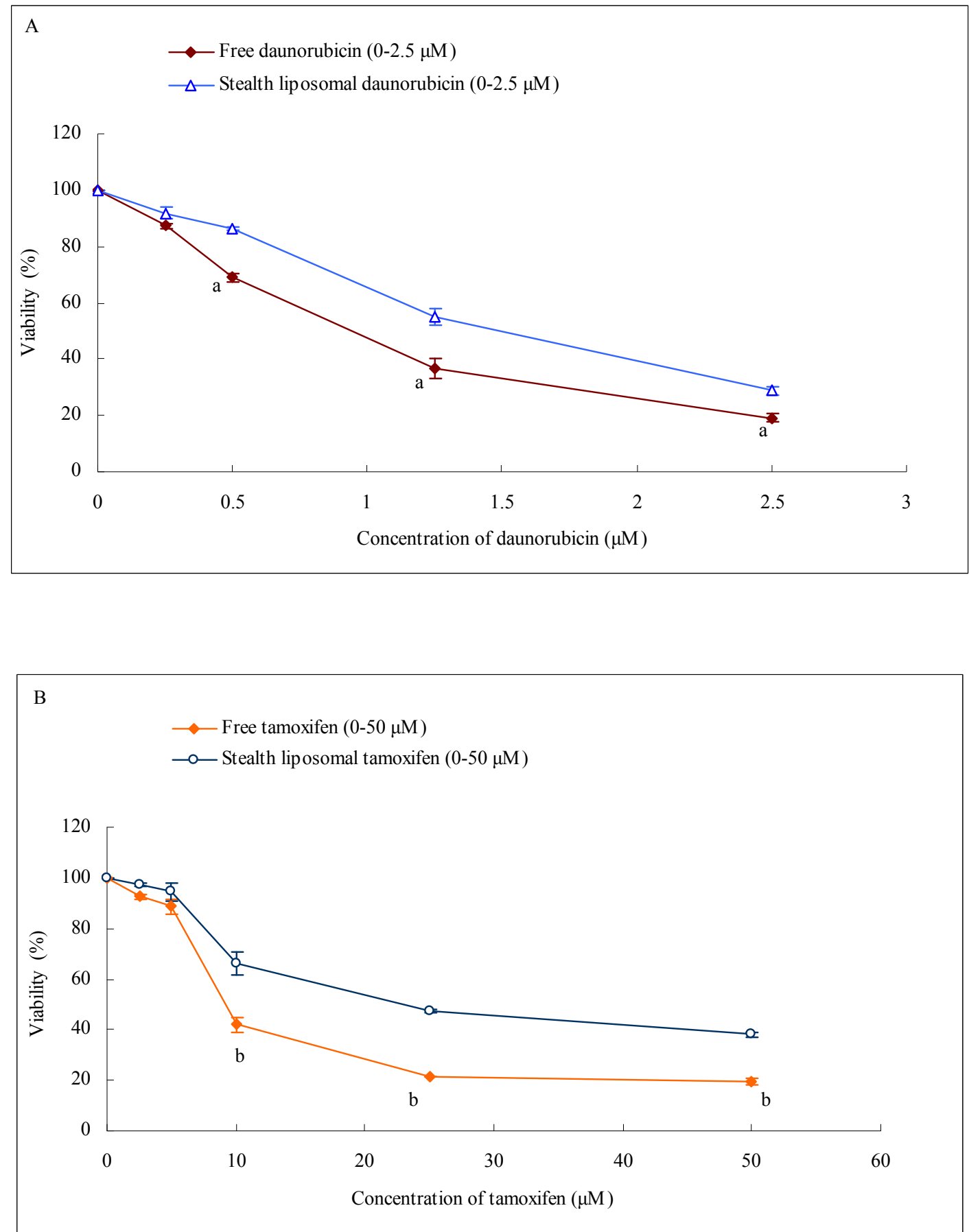

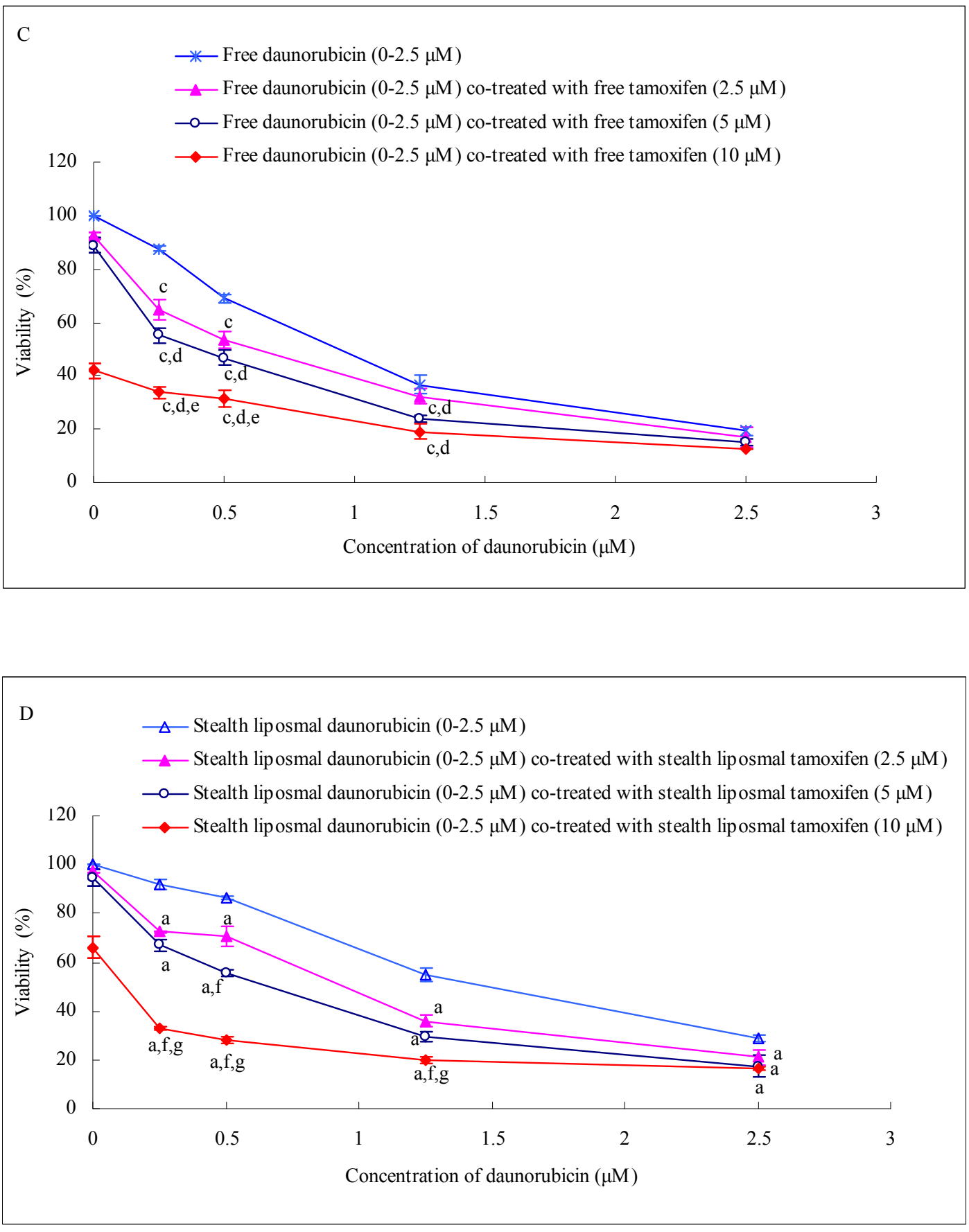

Figure 1. Effects on MCF-7 breast cancer cells after applying various formulations. A. Daunorubicin. B. Tamoxifen. C. Free daunorubicin $(0-2.5 \mu \mathrm{M})$ co-treated with free tamoxifen $(2.5,5,10 \mu \mathrm{M})$, respectively. D. Stealth liposomal daunorubicin $(0-2.5 \mu \mathrm{M})$ co-treated with stealth liposomal tamoxifen $(2.5,5,10 \mu \mathrm{M})$, respectively.

a, versus stealth liposomal daunorubicin;

$\mathrm{b}$, versus stealth liposomal tamoxifen;

c, versus free daunorubicin $(0-2.5 \mu \mathrm{M})$;

$\mathrm{d}$, versus free daunorubicin $(0-2.5 \mu \mathrm{M})$ co-treated with free tamoxifen $(2.5 \mu \mathrm{M})$;

$\mathrm{e}$, versus free daunorubicin $(0-2.5 \mu \mathrm{M})$ co-treated with free tamoxifen $(5 \mu \mathrm{M})$;

$\mathrm{f}$, versus stealth liposomal daunorubicin $(0-2.5 \mu \mathrm{M})$ co-treated with stealth liposomal tamoxifen $(2.5 \mu \mathrm{M})$; $\mathrm{g}$, versus stealth liposomal daunorubicin $(0-2.5 \mu \mathrm{M})$ co-treated with stealth liposomal amoxifen $(5 \mu \mathrm{M})$. 
Breast cancer stem cells were identified by the specific surface markers CD44+/CD24-. Approximately $1 \%$ SP cells were isolated from MCF-7 cells (Figure 2. B).

\section{Effect on the SP cells}

Figure 3 presents the inhibitory effect on the sorted breast cancer stem-like cells (SP) and breast cancer cells (NSP) following co-treating free daunorubicin with tamoxifen, or co-treating stealth liposomal daunorubicin with stealth liposomal tamoxifen. When treated with free tamoxifen $(1.5 \mu \mathrm{M})$ alone, its inhibitory effect to SP cells was similar to that to NSP cells, suggesting that tamoxifen was able to effectively inhibit both SP cells and NSP cells. In contrast, the inhibitory effect of free daunorubicin to SP cells was lower than that to NSP cells, suggesting that the SP cells were resistant to daunorubicin. However, free daunorubicin by co-treating free tamoxifen showed an obvious inhibitory effect to the SP cells. For example, when treated with free daunorubicin $(0.5 \mu \mathrm{M})$ alone, the inhibitory effects to SP cells and to NSP cells were $25.8 \%$, and $47.6 \%$, respectively. When co-treated free daunorubicin $(0.5 \mu \mathrm{M})$ with free tamoxifen $(1.5 \mu \mathrm{M})$, the inhibitory effect to SP cells was significantly increased to $69.8 \%$, and the inhibitory effect to NSP cells was also enhanced to $69.7 \%$ (Figure 3. A). Similar result was obtained after co-treating stealth liposomal daunorubicin with stealth liposomal tamoxifen (Figure 3. B).

\section{Antitumor efficacy in tumor xenografts in mice}

Figure 4 represents the change ratios of tumor volume (\%) after intravenous injection of stealth liposomal daunorubicin plus tamoxifen or various formulations as the controls. After inoculation, suitable tumor masses (approximately $200 \mathrm{~mm}^{3}$ ) appeared at day 18. After three administrations at day 18,20 and 22 , the inhibitory effects to tumor growth were evidently observed in all drug-treated groups, as compared to the blank control (physiological saline).

After treated with free daunorubicin $(5 \mathrm{mg} / \mathrm{kg})$ or free tamoxifen $(2.5 \mathrm{mg} / \mathrm{kg})$, the tumor growth was obviously inhibited. When co-treated free daunorubicin $(5 \mathrm{mg} / \mathrm{kg})$ with free tamoxifen $(2.5$ $\mathrm{mg} / \mathrm{kg}$ ), the inhibitory effect to the tumor growth, was slightly improved.
When comparing the antitumor effects between stealth liposomal daunorubicin $(5 \mathrm{mg} / \mathrm{kg})$ and free daunorubicin $(5 \mathrm{mg} / \mathrm{kg})$ or between stealth liposomal tamoxifen $(2.5 \mathrm{mg} / \mathrm{kg})$ and free tamoxifen $(2.5 \mathrm{mg} / \mathrm{kg})$, more strong inhibitory effects were observed in the groups administered as the drug-loaded stealth liposomes.

After treatment with stealth liposomal daunorubicin $(5 \mathrm{mg} / \mathrm{kg})$ plus tamoxifen $(1.25,2.5$ or $5 \mathrm{mg} / \mathrm{kg}$ ), the tumor growth was the most significantly inhibited, and the tumor volume was gradually shrunk, showing an optimal inhibitory effect.

\section{TUNEL analysis}

The TUNEL assay showed that the apoptotic percentages were $3.3 \pm 1.5 \%$ for the group treated with physiological saline (Figure 5. A), $8.0 \pm 2.0 \%$ for the group treated with free daunorubicin $(5 \mathrm{mg} / \mathrm{kg})$ (Figure 5. B), $5.7 \pm 2.5 \%$ for the group treated with free tamoxifen $(2.5 \mathrm{mg} / \mathrm{kg}$ ) (Figure 5 . C), $9.7 \pm 4.7 \%$ for the group treated with stealth liposomal daunorubicin $(5 \mathrm{mg} / \mathrm{kg}$ ) (Figure 5. D), $5.0 \pm 1.0 \%$ for the group treated with stealth liposomal tamoxifen $(2.5 \mathrm{mg} / \mathrm{kg}$ ) (Figure 5. E), $11.3 \pm 3.0 \%$ for the group co-treated free daunorubicin $(5 \mathrm{mg} / \mathrm{kg})$ with free tamoxifen $(2.5$ $\mathrm{mg} / \mathrm{kg}$ ) (Figure 5. F), $12.0 \pm 3.0 \%$ for the group treated with stealth liposomal daunorubicin (5 $\mathrm{mg} / \mathrm{kg}$ ) plus tamoxifen $(1.25 \mathrm{mg} / \mathrm{kg}$ ) (Figure 5. G) and $14.7 \pm 2.3 \%$ for the group treated with stealth liposomal daunorubicin $(5 \mathrm{mg} / \mathrm{kg})$ plus tamoxifen $(5 \mathrm{mg} / \mathrm{kg}$ ) (Figure 5. $\mathrm{H}$ ), respectively. In comparisons, stealth liposomal daunorubicin (5 $\mathrm{mg} / \mathrm{kg}$ ) plus tamoxifen $(5 \mathrm{mg} / \mathrm{kg}$ ) resulted in the more obvious inducing apoptotic effect.

\section{DISCUSSION}

The main finding of the present study was that the stealth liposomal daunorubicin plus tamoxifen was able to eliminate cancer cells together with the cancer stem cells. The PEGylated stealth liposomes were included for use because the liposomes coated with the synthetic polymer polyethylene glycol (PEG)-lipid derivative were able to avoid the rapid uptake by the reticuloendothelial system (RES), and had optimal stability which contributed to higher accumulation in the tumor tissues by the enhanced permeability and retention effect (EPR effect) $(21,34)$. 


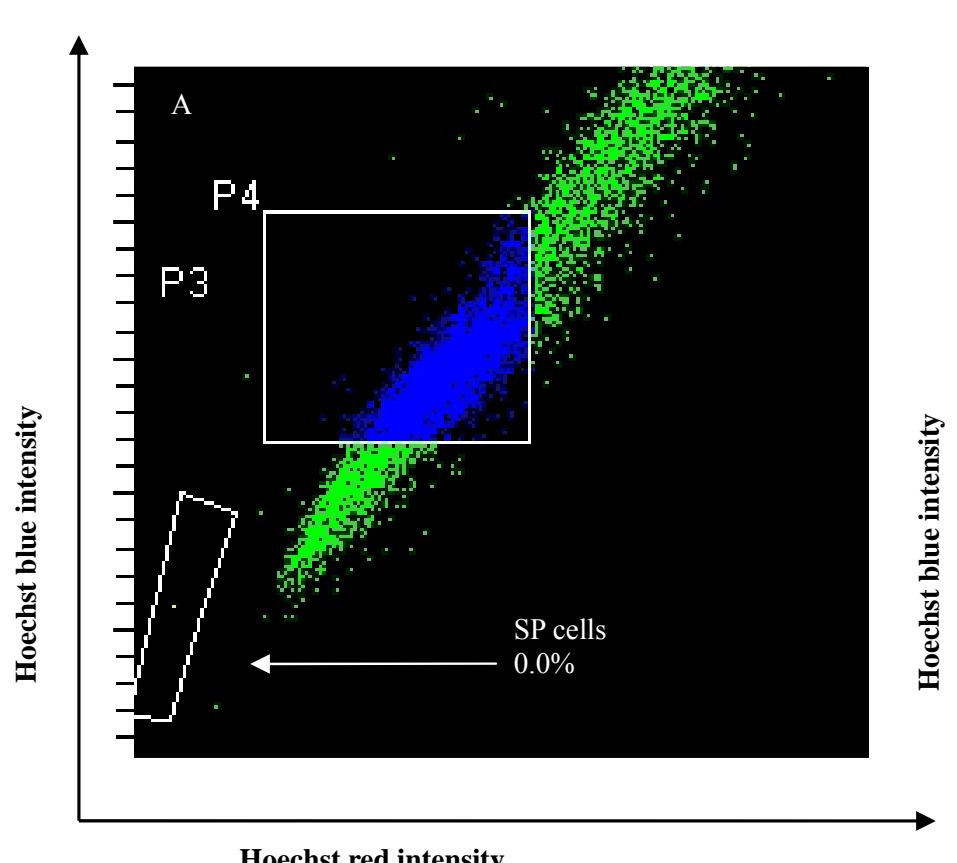

Hoechst red intensity

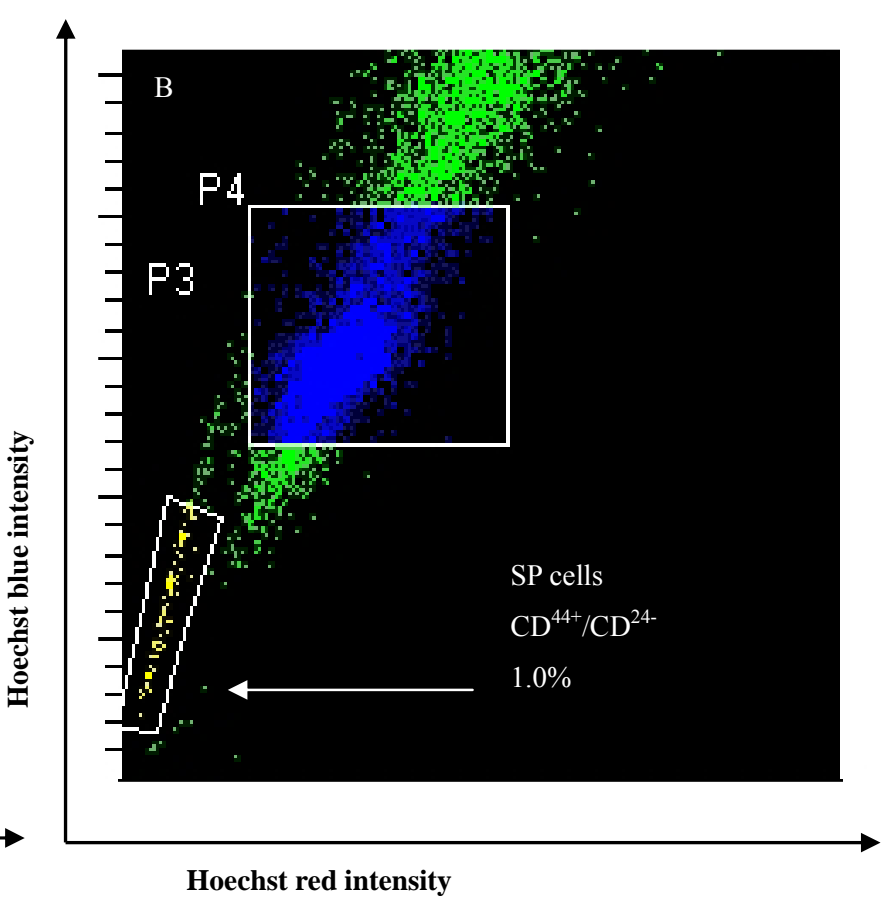

Hoechst red intensity

Figure 2. Identification of SP cells in human breast cancer cell lines. P3 gate represents the SP cells, and P4 gate denotes the NSP cells. A. MCF-7 cells were treated with verapamil $(200 \mu \mathrm{M})$ in advance, labeled with Hoechst 33342 and then analyzed by flow cytometry; B. MCF-7 cells were labeled with Hoechst 33342 and then analyzed by flow cytometry.

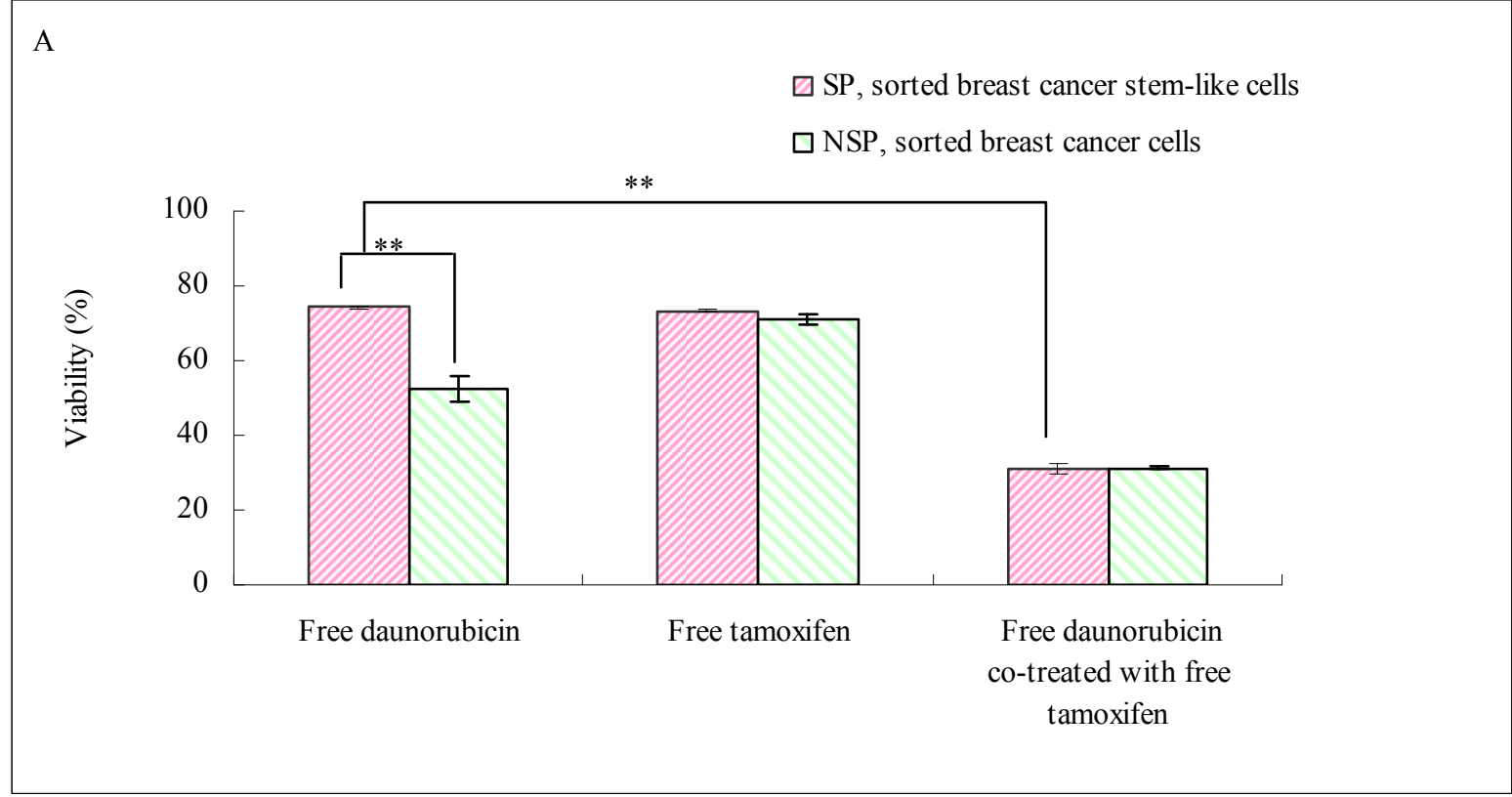




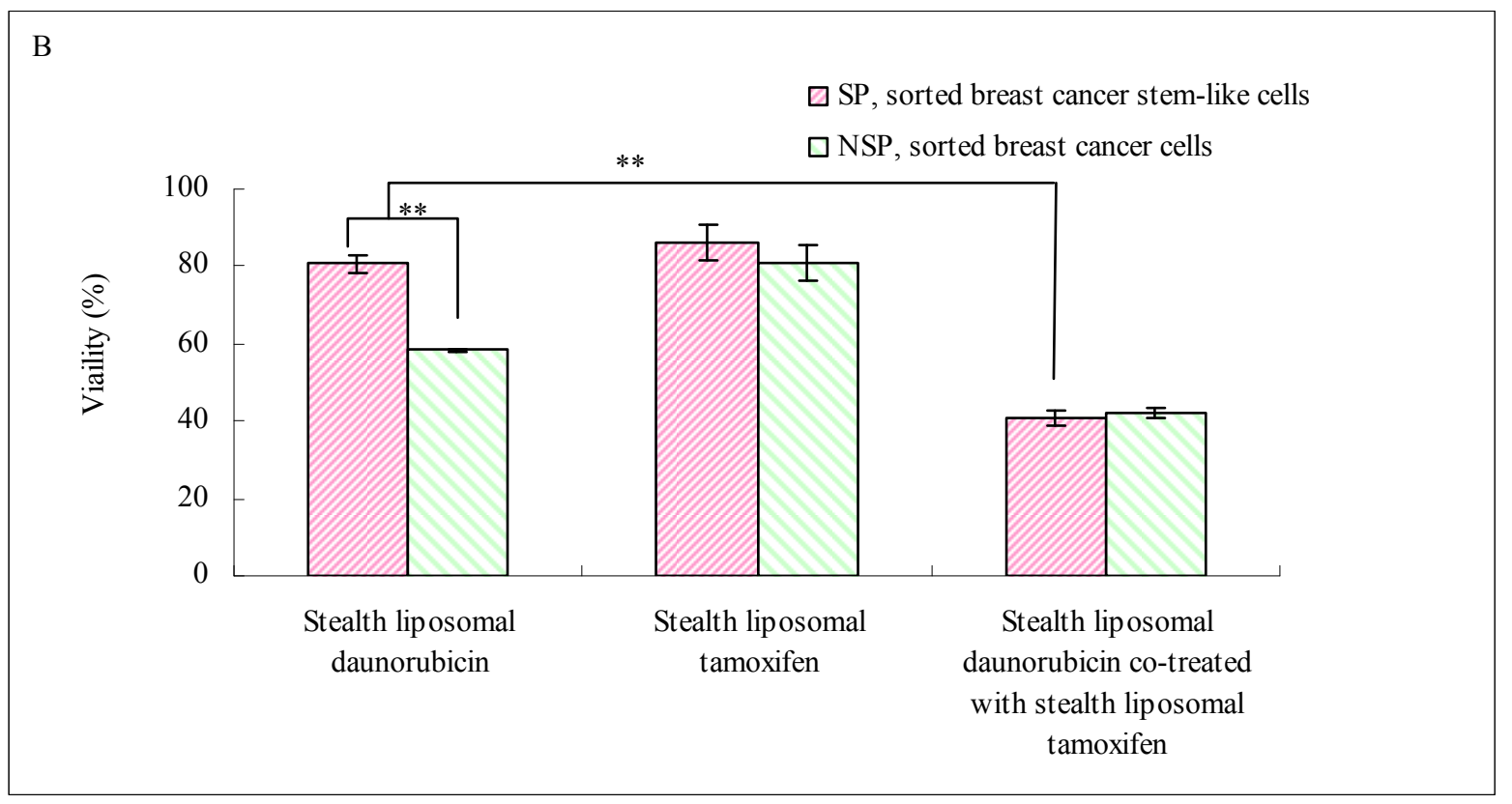

Figure 3. Effects on the sorted MCF-7 breast cancer stem-like cells (SP cells) and the sorted breast cancer cells (NSP cells) following applying various formulations: A, free tamoxifen $(1.5 \mu \mathrm{M})$, free daunorubicin $(0.5 \mu \mathrm{M})$, and free daunorubicin $(0.5 \mu \mathrm{M})$ co-treated with free tamoxifen $(1.5 \mu \mathrm{M})$; B, stealth liposomal tamoxifen $(1.5 \mu \mathrm{M})$, stealth liposomal daunorubicin $(0.5 \mu \mathrm{M})$, and stealth liposomal daunorubicin $(0.5 \mu \mathrm{M})$ co-treated with stealth liposomal tamoxifen $(1.5 \mu \mathrm{M})$.

$* * p<0.05$.

Daunorubicin and tamoxifen were incorporated into the same vesicle of one liposome because the liposomal encapsulation would be beneficial for the simultaneous action of both drugs in the tumor site. Moreover, the systemic side effects of chemotherapeutic agents were minimized by lowering the drug concentrations in non-target organs and tissues (40) and by the indirect exposure to blood circulation system.

Results from the characterization indicated that the stealth liposomal daunorubicin plus tamoxifen was of benefit to its therapeutic activity because of its smaller particle size $(100 \mathrm{~nm})$ which led to the enhanced permeability and retention effect in solid tumors $(41,42)$. A narrow PDI for the stealth liposomes showed that they were homogeneous. All three kinds of liposomes were slightly negatively charged and the variations in negativity were observed. The reduction in negativity of stealth liposomal daunorubicin plus tamoxifen could be explained by the fact that tamoxifen, as a neutral molecule, contributed to delocalize the negative charge centers, resulting in an increased zeta potential value of stealth liposomal daunorubicin plus tamoxifen when compared with that of stealth liposomal daunorubicin.

Previously, we had developed a tumor stem cell targeting liposomal system by a combination use of liposomal vinorelbine with liposomal parthenolide (PTL) in which parthenolide acted as a specific agent having capability of killing tumor stem cells $(14,43)$. During the further studies, the parthenolide was found to easily "escape" from the liposome surface resulting in the instability of the liposomal parthenolide. Tamoxifen was selected due to its ability in evidently killing the breast cancer stem cells at the early screening, and the stability of the tamoxifen-loaded liposomes in our preliminary studies. In addition, tamoxifen had been used in treating patients with early-stage breast cancer (44), and with metastatic breast cancer (45), suggesting that tamoxifen may potentially be capable of eliminating the breast cancer stem cells. Consequently, our hypothesis of the present study was based on these considerations. 


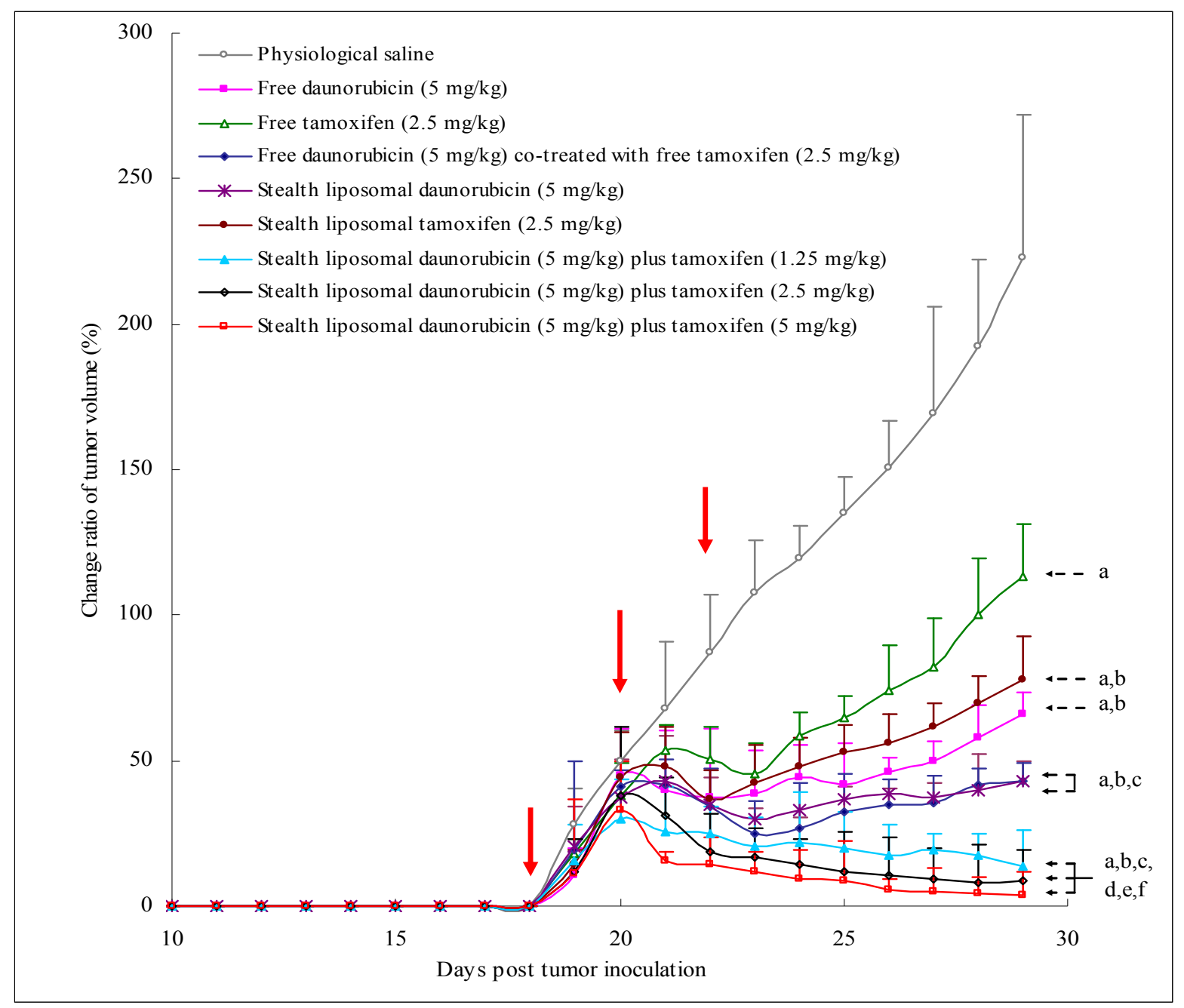

Figure 4. Effects on the tumor growth of MCF-7 xenografts in female nude mice after injections trhough tail vein of physiological saline, free daunorubicin $(5 \mathrm{mg} / \mathrm{kg})$, free tamoxifen $(2.5 \mathrm{mg} / \mathrm{kg})$, free daunorubicin $(5 \mathrm{mg} / \mathrm{kg})$ co-treated with free tamoxifen $(2.5 \mathrm{mg} / \mathrm{kg})$, stealth liposomal daunorubicin $(5 \mathrm{mg} / \mathrm{kg})$, stealth liposomal tamoxifen $(2.5 \mathrm{mg} / \mathrm{kg})$, stealth liposomal daunorubicin $(5 \mathrm{mg} / \mathrm{kg})$ plus tamoxifen $(5 \mathrm{mg} / \mathrm{kg})$. stealth liposomal daunorubicin $(5 \mathrm{mg} / \mathrm{kg})$ plus tamoxifen $(2.5 \mathrm{mg} / \mathrm{kg})$, stealth liposomal daunorubicin $(5 \mathrm{mg} / \mathrm{kg})$ plus tamoxifen $(1.25 \mathrm{mg} / \mathrm{kg})$ at day $18,20,22$ post tumor inoculation, respectively. Data are presented as the mean \pm standard deviation $(\mathrm{n}=4-6)$.

a, $p<0.05$, versus physiological saline;

$\mathrm{b}, p<0.05$, versus free tamoxifen $(2.5 \mathrm{mg} / \mathrm{kg})$;

c, $p<0.05$, versus stealth liposomal tamoxifen $(2.5 \mathrm{mg} / \mathrm{kg})$;

$\mathrm{d}, p<0.05$, versus free daunorubicin $(5 \mathrm{mg} / \mathrm{kg})$;

$\mathrm{e}, p<0.05$, versus free daunorubicin $(5 \mathrm{mg} / \mathrm{kg})$ co-treated with free tamoxifen $(2.5 \mathrm{mg} / \mathrm{kg})$;

f, $p<0.05$, versus stealth liposomal daunorubicin $(5 \mathrm{mg} / \mathrm{kg})$.

To elucidate the overall effect, daunorubicin and tamoxifen were firstly applied to bulk breast cancer cells (a mixture of breast cancer cells and cancer stem cells). Results demonstrated that both daunorubicin and stealth liposomal daunorubicin were able to effectively kill the breast cancer cells but exhibited different inhibitory effects at the same dose level. The difference was due to the liposomal encapsulation of drugs. Because the liposome-cell interactions were via four possible modes: adsorption, endocytosis, fusion, and lipid transfer. 

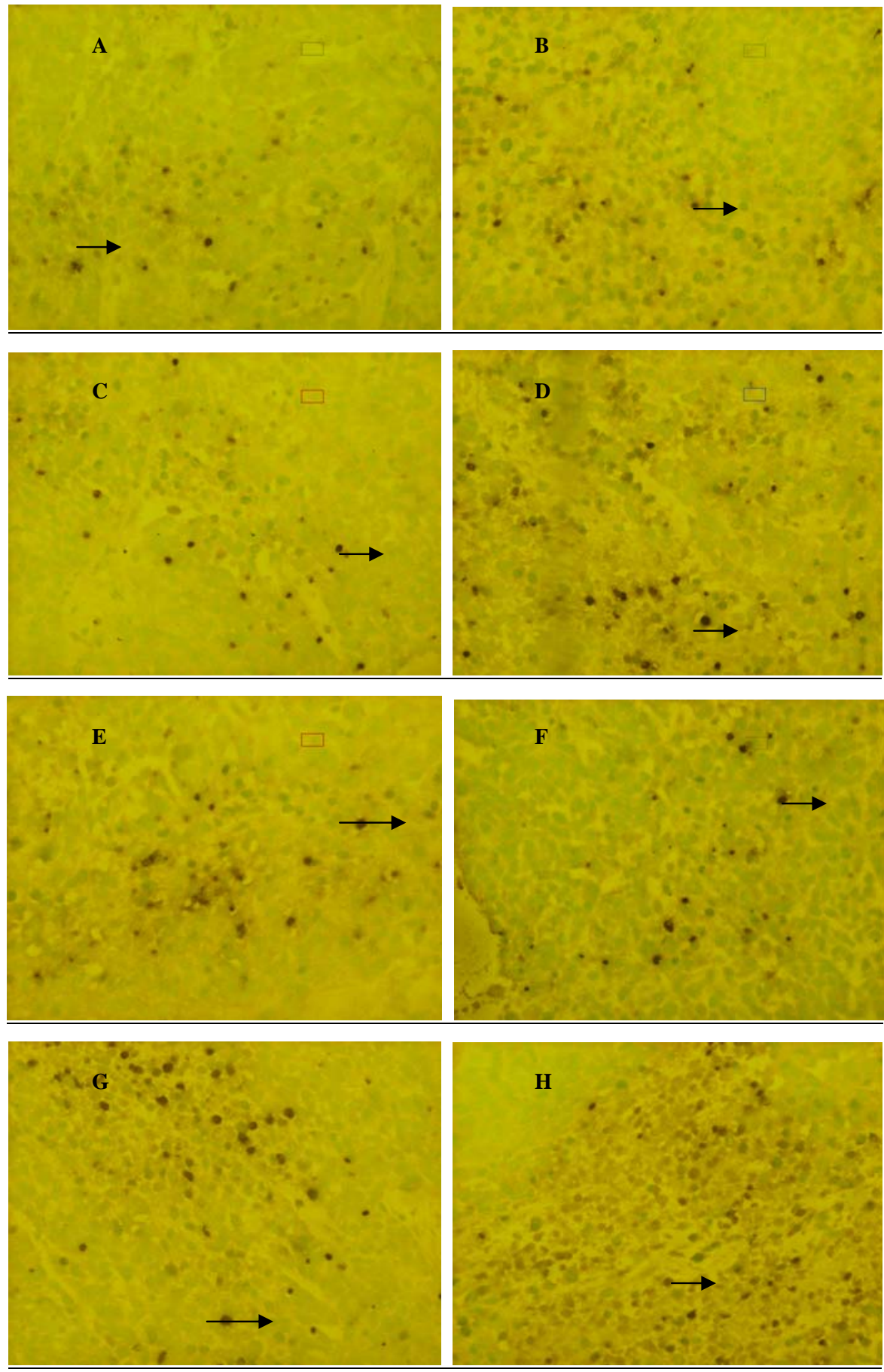

Figure 5. Paraffin sections showing TUNEL-labeled cells in the tumor tissues at day 29 after inoculation of MCF-7 in the female nude mice $(\times 400)$. Apoptotic cells (shown by arrowhead) are characterized by a dense staining of nuclei. The MCF-7 xenografted mice were given intravenously with physiological saline as a blank control (A), free daunorubicin $(5 \mathrm{mg} / \mathrm{kg})$ (B), free tamoxifen $(2.5 \mathrm{mg} / \mathrm{kg})$ (C), stealth liposomal daunorubicin (5mg/kg) (D), stealth liposomal tamoxifen $(2.5 \mathrm{mg} / \mathrm{kg})(\mathbf{E})$, free daunorubicin $(5 \mathrm{mg} / \mathrm{kg})$ co-treated with free tamoxifen $(2.5 \mathrm{mg} / \mathrm{kg})(\mathbf{F})$, stealth liposomal daunorubicin $(5 \mathrm{mg} / \mathrm{kg})$ plus tamoxifen $(1.25 \mathrm{mg} / \mathrm{kg})(\mathbf{G})$, stealth liposomal daunorubicin $(5 \mathrm{mg} / \mathrm{kg}) \mathrm{plus}$ tamoxifen $(5 \mathrm{mg} / \mathrm{kg}) \mathbf{( H )}$, respectively. 
Under the condition in vitro, these interactions could retard the inhibitory effect of stealth liposomal daunorubicin to the breast cancer cells, while free drugs acted on the cancer cells via direct exposure. This situation has been reversely changed in animals, namely, administration of stealth liposomal daunorubicin plus tamoxifen showed more favorable inhibitory effect as compared to free daunorubicin plus free tamoxifen, as discussed below. The phenomenon has also been found in our other investigations $(14,34)$. Similar phenomenon was also observed after treating with stealth liposomal tamoxifen.

A lower dose of free tamoxifen alone or stealth liposomal tamoxifen alone did not exhibit obviously inhibitory activity until the dose of tamoxifen reached a higher level $(\geq 10 \mu \mathrm{M})$. A recent report showed that the high dose of tamoxifen was able to trigger the active cell death and macroautophagy of MCF-7 cells (46). The previous reports showed that the combination therapy of anthracyclines and tamoxifen did not result in significant synergistic inhibition to MCF-7 cells $(47,48)$. These may be associated with a lower concentration of tamoxifen accessed into the breast cancer cells by regular administrations in patients. In the present study, co-treating stealth liposomal duanorubicin with a lower dose of stealth liposomal tamoxifen resulted in synergistically inhibitory effect to the breast cancer cells.

To define the effect on the breast cancer stem cells, SP cells should be identified and isolated from the bulk breast cancer cells. In the present study, the identification and isolation procedures were identical to our previous report (14). The stem-like characteristics of the isolated SP cells were further confirmed by expressing specific markers CD44+/CD24- and having a higher proliferation rate (data not shown).

Results from cytotoxicity studies on the isolated SP and NSP cells demonstrated that daunorubicin had a higher inhibitory effect to NSP cells when compared to SP cells, proving that daunorubicin was resistant to the cancer stem cells. In contrast, tamoxifen alone or a combination of daunorubicin with tamoxifen exhibited a significant inhibitory effect to the sorted SP cells. The most likely reason could be associated with the mechanism which tamoxifen could inhibit BCRP and MDR1 proteins overexpressed on the breast cancer stem cells $(32,33)$. When co-treating with tamoxifen, an enhanced inhibitory effect of daunorubicin to cancer stem cells was observed due to the effect of tamoxifen on the $\mathrm{ABC}$ transporters by blocking the efflux of daunorubicin from breast cancer stem cells. In addition, tamoxifen itself could also induce the active cell death and macroautophagy of breast cancer stem cells by modulating cholesterol metabolism (46). Similar findings were obtained when applying stealth liposomal daunorubicin plus tamoxifen.

In vivo results proved that the stealth liposomal daunorubicin plus tamoxifen showed an optimal antitumor activity in the MCF-7 xenografts in mice. The possible reasons could be due to multiple aspects. Firstly, the PEG-modified stealth liposomes had a longer circulatory half-life and were beneficial for their passive targeting the tumor tissue via the EPR effect, thus making the drug-loaded liposomes accumulate more in the solid tumors (49). Secondly, stealth liposomal daunorubicin plus tamoxifen resulted in a synergistically inhibitory effect to the tumors. In contrast, administration of two kinds of free drugs would result in different distributions in animals, thereby leading to a lower inhibitory effect or a lower synergistic effect to the tumor tissue. Finally, as a result of the elimination of the caner stem cells by tamoxifen, the self-proliferative potential of tumors was diminished. When comparing the results among three groups administered as stealth liposomal daunorubicin plus tamoxifen, their inhibitory effects were increased with the dose escalation of tamoxifen, indicating that tamoxifen has potential in the complete eliminating the breast cancer cells together with cancer stem cells. TUNEL analysis further displayed that the stealth liposomal daunorubicin plus tamoxifen generated the most optional pro-apoptotic effect in the xenografts, thereby contributing to the global antitumor activity.

In summary, the stealth liposomal daunorubicin plus tamoxifen was constructed for eliminating both breast cancer cells and cancer stem cells. Breast cancer stem cells were identified by the specific markers CD44+/CD24-, and isolated from total MCF-7 cells. Daunorubicin itself was resistant to the breast cancer stem cells. When applying stealth liposomal daunorubicin plus tamoxifen, the inhibitory effects on both the breast cancer cells and the cancer stem cells were significantly increased in vitro, respectively. In the MCF-7 xenografts in mice, stealth liposomal daunorubicin plus tamoxifen showed the most satisfactory 
antitumor activity due to their suitable particle size, passive targeting to the tumor tissue, and synergistic effects in eliminating breast cancer cells and cancer stem cells. It could be concluded that the therapy using stealth liposomal daunorubicin plus tamoxifen may provide a potential strategy for hampering relapse and metastasis by eradicating both bulk breast cancer cells and cancer stem cells.

\section{ACKNOWLEDGEMENTS}

This paper was supported by the Grant of National Science Foundation of China (No. 30772664), in part by the National Key Science Research Program of China (973 program, 2009CB930300), and in part by the Grant of Doctoral Program of Education Ministry of China (No. 20070001741).

\section{REFERENCES}

1. World Health Organization, 2006. "Fact sheet No. 297: Cancer", http://www.who.int/mediacentre/factsheets/fs297/en /index.html. Retrieved on 2009- 03-26

2. Curry EA 3rd, Murry DJ, Yoder C, Fife K, Armstrong V, Nakshatri H, O'Connell M, Sweeney CJ. Phase I dose escalation trial of feverfew with standardized doses of parthenolide in patients with cancer. Invest. New Drugs, 2004; 22:299-305.

3. Reya T, Morrison SJ, Clarke MF, Weissman IL. Stem cells, cancer, and cancer stem cells. Nature, 2001; 414:105-11.

4. Pardal R, Clarke MF, Morrison SJ. Applying the principles of stem-cell biology to cancer. Nat Rev Cancer, 2003; 3:895-902.

5. Dean M, Fojo T, Bates S. Tumor stem cells and drug resistance. Nat Rev Cancer, 2005; 5:275-84.

6. Hadnagy A, Gaboury L, Beaulieu R, Balicki D. SP analysis may be used to identify cancer stem cell populations. Exp Cell Res, 2006; 312:3701-10.

7. Chuthapisith S, Eremin J, El-Sheemey M, Eremin O. Breast cancer chemoresistance: Emerging importance of cancer stem cells. Surg Oncol, 2010; 19:27-32.

8. Michael FC. A self-renewal assay for cancer stem cells. Cancer Chemother Pharmacol, 2005; 56:64-8.

9. Zhang M, Rosen JM. Stem cells in the etiology and treatment of cancer. Curr Opin Genet Dev, 2006; 16:60-4.

10. Moserle L, Ghisi M, Amadori A, Indraccolo S. Side population and cancer stem cells: Therapeutic implications. Cancer Lett, 2010; 288:1-9.

11. Chu TS, Chen JS, Lopez JP, Pardo FS, Aguilera J, Ongkeko WM. Imatinib-mediated inactivation of Akt regulates ABCG2 function in head and neck squamous cell carcinoma. Arch Otolaryngol Head Neck Surg, 2008; 134:979-84.

12. Stewart S. Stem cell origin of cancer and differentiation therapy. Critical Reviews in Oncology/Hematology 2004; 51:1-28.

13. Al-Hajj M, Wicha MS, Benito-Hernandez A, Morrison SJ, Clarke MF. Prospective identification of tumorigenic breast cancer cells. Proc Natl Acad Sci USA, 2003; 100:3983-88.

14. Liu Y, Lu WL, Guo J, Du J, Li T, Wu JW, Wang GL, Wang JC, Zhang X, Zhang Q. A potential target associated with both cancer and cancer stem cells: a combination therapy for eradication of breast cancer using vinorelbine stealthy liposomes plus parthenolide stealthy liposomes. J Control Release, 2008; 129:18-25.

15. Patrawala L, Calhoun T, Schneider-Broussard R, Zhou J, Claypool K, Tang DG. Side population is enriched in tumorigenic, stem-like cancer cells, whereas ABCG2+ and ABCG2- cancer cells are similarly tumorigenic. Cancer Res, 2005; 65:6207-19.

16. Kondo T, Setoguchi T, Taga T. Persistence of a small subpopulation of cancer stem-like cells in the C6 glioma cell line. Proc Natl Acad Sci USA, 2004; 101:781-6.

17. Chiba T, Kita K, Zheng YW, Yokosuka O, Saisho H, Iwama A, Nakauchi H, Taniguchi H. Side population purified from hepatocellular carcinoma cells harbors cancer stem cell-like properties. Hepatology, 2006; 44:240-51.

18. Mitsutake N, Iwao A, Nagai K, Namba H, Ohtsuru A, Saenko V, Yamashita S. Characterization of side population in thyroid cancer cell lines: cancer stem-like cells are enriched partly but not exclusively. Endocrinology, 2007; 148:1797-803.

19. Haraguchi N, Utsunomiya T, Inoue H, Tanaka F, Mimori K, Barnard GF, Mori M. Characterization of a side population of cancer cells from human gastrointestinal system. Stem Cells, 2006; 24:506-513.

20. Szotek PP, Pieretti-Vanmarcke R, Masiakos PT, Dinulescu DM, Connolly D, Foster R, Dombkowski D, Preffer F, Maclaughlin DT, Donahoe PK. Ovarian cancer side population defines cells with stem cell-like characteristics and Mullerian Inhibiting Substance responsiveness. Proc Natl Acad Sci USA, 2006; 103:11154-9.

21. Andresen TL, Jensen SS, Jørgensen K. Advanced strategies in liposomal cancer therapy: problems and prospects of active and tumor specific drug release. Andresen Prog Lipid Res, 2005; 44:68-97.

22. Weiss RB. The anthracyclines: will we ever find a better doxorubicin? Semin Oncol, 1992; 19:670-86.

23. Marczak A, Wrzesień-Kuś A, Krykowski E, Robak T, Júźwiak Z. The interaction of daunorubicin and 
mitoxantrone with the red blood cells of acute myeloid leukemia patients. Cell Mol Biol Lett, 2003; 8:885-90.

24. Simeonova M, Ivanova G, Enchev V, Markova N, Kamburov M, Petkov C, Devery A, O'Connor R, Brougham D. Reversal of breast cancer resistance protein-mediated drug resistance by estrogen antagonists and agonists. Acta Biomater, 2009; 5:2109-21.

25. Lotfi K, Zackrisson AL, Peterson C. Comparison of idarubicin and daunorubicin regarding intracellular uptake, induction of apoptosis, and resistance. Cancer Lett, 2002; 178: 141-9.

26. Minotti G, Menna P, Salvatorelli E, Cairo G, Gianni L. Anthracyclines: molecular advances and pharmacologic developments in antitumor activity and cardiotoxicity. Pharmacol Rev, 2004; 56:185-229.

27. Rabbani A, Finn RM, Ausió J. The anthracycline antibiotics: antitumor drugs that alter chromatin structure. Bioessays, 2005; 27:50-6.

28. Zucchi R, Danesi R. Cardiac toxicity of antineoplastic anthracyclines. Curr Med Chem Anticancer Agents, 2003; 3:151-71.

29. Endicott JA, Ling V. The biochemistry of P-glycoprotein-mediated multidrug resistance. Annu Rev Biochem, 1989; 58:137-71.

30. da Rocha AB, Mans DR, Bernard EA, Ruschel C, Logullo AF, Wetmore LA, Leyva A, Schwartsmann G. Tamoxifen inhibits particulate-associated protein kinase $\mathrm{C}$ activity, and sensitises cultured human glioblastoma cells not to etoposide but to gamma-radiation and BCNU. Eur J Cancer, 1999; 35: 833-9.

31. Han P, Kang JH, Li HL, Hu SX, Lian HH, Qiu PP, Zhang J, Li WG, Chen QX. Antiproliferation and apoptosis induced by tamoxifen in human bile duct carcinoma QBC939 cells via upregulated p53 expression. Biochem Biophys Res Commun, 2009; 385:251-6.

32. Bekaii-Saab TS, Perloff MD, Weemhoff JL, Greenblatt DJ, von Moltke LL. Interactions of tamoxifen, N-desmethyltamoxifen and 4-hydroxytamoxifen with P-glycoprotein and CYP3A. Biopharm Drug Dispos, 2004; 25:283-9.

33. Sugimoto Y, Tsukahara S, Imai Y, Sugimoto Y, Ueda $\mathrm{K}$, Tsuruo T. Reversal of breast cancer resistance protein-mediated drug resistance by estrogen antagonists and agonists. Mol Cancer Ther, 2003; 2: 105-12.

34. Li X, Ruan GR, Lu WL, Hong HY, Liang GW, Zhang YT, Liu Y, Long C, Ma X, Yuan L, Wang JC, Zhang X, Zhang Q. A novel stealth liposomal topotecan with amlodipine: apoptotic effect is associated with deletion of intracellular $\mathrm{Ca} 2+$ by amlodipine thus leading to an enhanced antitumor activity in leukemia. J Control Release, 2006; 112:186-98.

35. Ying X, Wen H, Lu WL, Du J, Guo J, Tian W, Men Y, Zhang Y, Li RJ, Yang TY, Shang DW, Lou JN, Zhang LR, Zhang Q. Dual-targeting daunorubicin liposomes improve the therapeutic efficacy of brain glioma in animals. J Control Release, 2010; 141:183-92.

36. Klamt F, Passos DT, Castro MA, Gelain DP, Grivicich I, Moreira JC. Inhibition of MDR1 expression by retinol treatment increases sensitivity to etoposide (VP16) in human neoplasic cell line. Toxicol In Vitro, 2008; 22:873-8.

37. Houghton P, Fang R, Techatanawat I, Steventon G, Hylands PJ, Lee CC. The sulphorhodamine (SRB) assay and other approaches to testing plant extracts and derived compounds for activities related to reputed anticancer activity. Methods, 2007; 42:377-87.

38. Hirschmann-Jax C, Foster AE, Wulf GG, Nuchtern JG, Jax TW, Gobel U, Goodell MA, Brenner MK. A distinct "side population" of cells with high drug efflux capacity in human tumor cells. Proc Natl Acad Sci USA, 2004; 101:14228-33.

39. Foster PA, Newman SP, Chander SK, Stengel C, Jhalli R, Woo LL, Potter BV, Reed MJ, Purohit A. In vivo efficacy of STX213, a second-generation steroid sulfatase inhibitor, for hormone-dependent breast cancer therapy. Clin Cancer Res, 2006; 12:5543-9.

40. Iffert T, Soldan M, Moeller A, Maser E. Modulation of daunorubicin toxicity by liposomal encapsulation and use of specific inhibitors in vitro. Toxicology, 2000; 144:189-95.

41. Bally MB, Nayar R, Masin D, Cullis PR, Mayer LD. Studies on the myelosuppressive activity of doxorubicin entrapped in liposomes. Cancer Chemother Pharmacol, 1990; 27: 13-9.

42. Nagayasu A, Uchiyama K, Kiwada H. The size of liposomes: a factor which affects their targeting efficiency to tumors and therapeutic activity of liposomal antitumor drugs. Adv Drug Deliv Rev, 1999; 40:75-87.

43. Guzman ML, Rossi RM, Karnischky L, Li X, Peterson DR, Howard DS, Jordan CT. The sesquiterpene lactone parthenolide induces apoptosis of human acute myelogenous leukemia stem and progenitor cells. Blood, 2005; 105:4163-9.

44. Harlan LC, Klabunde CN, Ambs AH, Gibson T, Bernstein L, McTiernan A, Meeske K, Baumgartner $\mathrm{KB}$, Ballard-Barbash R. Comorbidities, therapy, and newly diagnosed conditions for women with early stage breast cancer. J Cancer Surviv, 2009; 3: 89-98.

45. Visvanathan K, Chlebowski RT, Hurley P, Col NF, Ropka M, Collyar D, Morrow M, Runowicz C, Pritchard KI, Hagerty K, Arun B, Garber J, Vogel 
VG, Wade JL, Brown P, Cuzick J, Kramer BS, Lippman SM; American Society of Clinical Oncology. American society of clinical oncology clinical practice guideline update on the use of pharmacologic interventions including tamoxifen, raloxifene, and aromatase inhibition for breast cancer risk reduction. J Clin Oncol, 2009; 27:3235-58.

46. de Medina P, Payré B, Boubekeur N, Bertrand-Michel J, Tercé F, Silvente-Poirot S, Poirot M. Ligands of the antiestrogen-binding site induce active cell death and autophagy in human breast cancer cells through the modulation of cholesterol metabolism. Cell Death Differ, 2009; 16:1372-84.

47. Woods KE, Randolph JK, Gewirtz DA. Antagonism between tamoxifen and doxorubicin in the MCF-7 human breast tumor cell line. Biochem Pharmacol, 1994; 47:1449-52.

48. Panasci L, Jean-Claude BJ, Vasilescu D, Mustafa A, Damian S, Damian Z, Georges E, Liu Z, Batist G, Leyland-Jones B. Sensitization to doxorubicin resistance in breast cancer cell lines by tamoxifen and megestrol acetate. Biochem Pharmacol, 1996; 52:1097-102.

49. Ogawara K, Un K, Minato K, Tanaka K, Higaki K, Kimura T. Determinants for in vivo antitumor effects of PEG liposomal doxorubicin: importance of vascular permeability within tumors. Int J Pharm, 2008; 359:234-40. 